\title{
Pengembangan Ekstrak Etanol Limbah Biji Pepaya (Carica papaya L.) Sebagai Serum Antijerawat
}

\author{
A. Hasrawati ${ }^{1}$, Hardianti ${ }^{2}$, Adisti Qama ${ }^{3}$, Muh. Wais ${ }^{4}$ \\ ${ }^{1234}$ Fakultas Farmasi, Universitas Muslim Indonesia
}

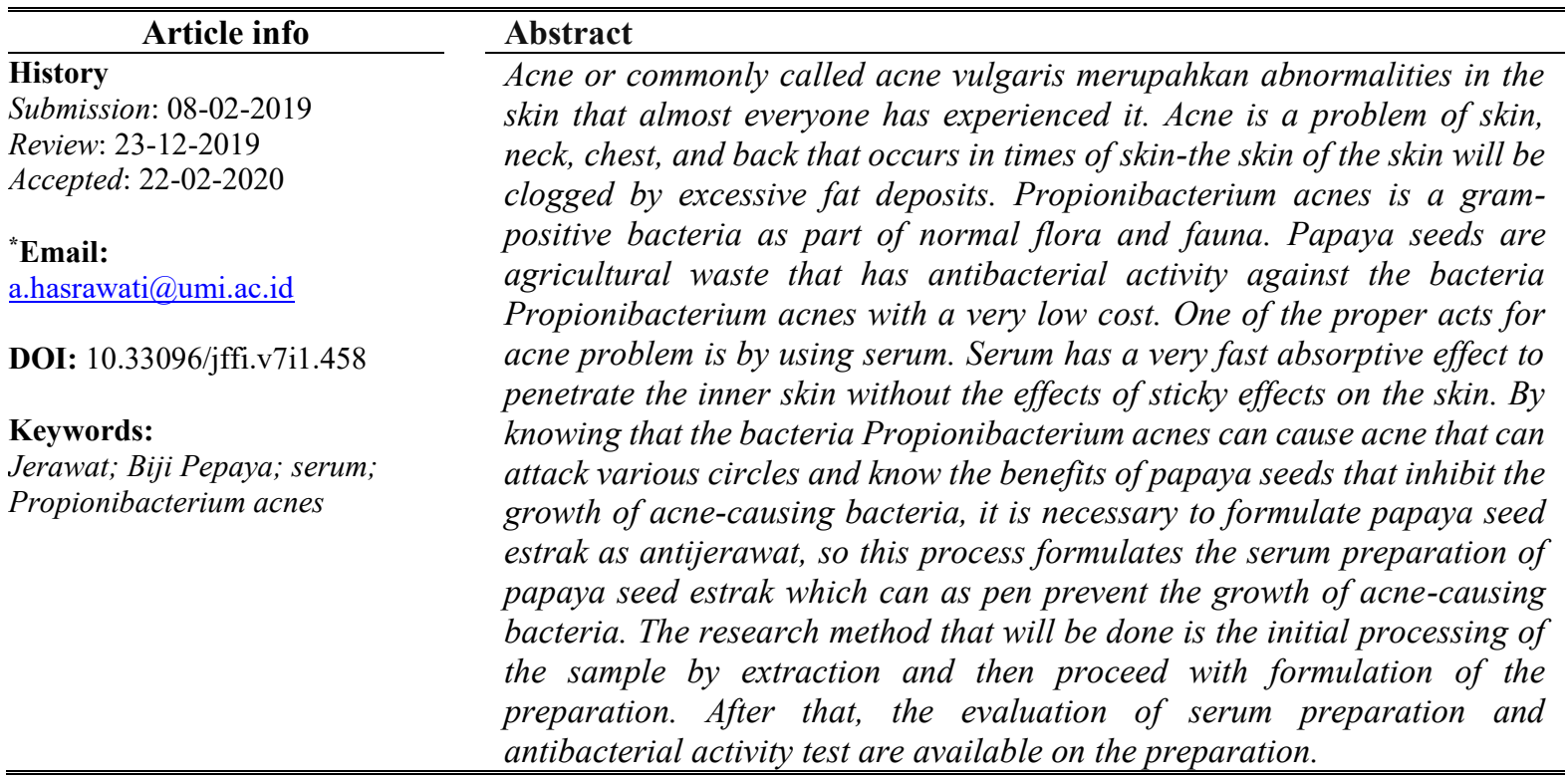

\section{Pendahuluan}

Jerawat atau acne vulgaris adalah masalah kulit berupa infeksi dan peradangan pada unit pilosebasea. Acne sering membuat resah dan menghilangkan rasa percaya diri, apalagi jika area kulit yang berjerawat sangat luas (Kurniawati, 2014). Acne vulgaris adalah kondisi yang sangat umum yang mempengaruhi lebih dari 80-90\% remaja dan dewasa muda. Biasanya dimulai pada masa kanak-kanak atau remaja awal, tapi onset mungkin tertunda pada beberapa orang sampai usia 20 dan 30an. Tingkat kejadian jerawat kira-kira sama pada laki-laki dan perempuan tetapi, laki-laki cenderung memiliki kondisi yang lebih serius (Draelos, 2006).

Untuk mengetahui perawatan terbaik untuk jerawat, penting untuk memahami penyebab jerawat yang bervariasi. Salah satu faktor yang menyebabkan terjadinya jerawat yaitu bakteri. (Mitzui, 1997). Propionibacterium acnes merupakan bakteri gram positif berbentuk batang dan merupakan flora normal kulit yang ikut berperan dalam pembentukan jerawat (Rahmi, 2015).

Jerawat biasanya sulit diatasi pada usia berapa pun, dan bisa menyebabkan depresi dan kecemasan sosial pada orang dewasa dan begitupun pada remaja. Bagi remaja, jerawat bisa menjadi salah satu hal buruk yang pernah terjadi. Jerawat sering membuat remaja merasa malu dan menurunkan kepercayaan diri mereka (Draelos, 2010).

Salah satu pengobatan yang tepat untuk masalah jerawat yaitu dengan menggunakan serum. Serum adalah sediaan dengan viskositas yang rendah yang menghantarkan zat aktif melalui permukaan kulit dengan membentuk lapisan film tipis dengan mengandung bahan aktif lebih banyak dan sedikit kandungan pelarut sehingga memilki kecenderungan konsentrat (Draelos, 2010).

Biji pepaya merupakan sampah pertanian yang memiliki aktivitas antibakteri terhadap bakteri Staphylococcus aureus dan terhadap Propionibacterium acnes (Syarifah, 2015). Dengan memahami bahwa bakteri Propionibacterium acnes dapat menyebabkan jerawat yang dapat menyerang berbagai kalangan dan mengetahui manfaat dari biji pepaya yang mencegah pertumbuhan bakteri penyebab jerawat, maka perlu dilakukan formulasi estrak biji pepaya sebagai antijerawat, sehingga riset ini berupaya memformulsi dalam sediaan serum agar dapat memberikan efek dan hasil yang akan langsung terlihat.

Tujuan dari penelitian ini untuk memformulasi sediaan serum dari ekstrak etanol limbah biji pepaya (Carica papaya L.) yang stabil secara farmasetik dan dapat digunakan sebagai antijerawat. Dengan rumusan masalah terkait bagaimana memformulasi ekstrak etanol biji pepaya dalam bentuk sediaan serum, bagaimana pengaruh 
basis terhadap stabilitas sediaan serum ekstrak etanol biji pepaya, bagaimana aktivitas serum ekstrak etanol biji pepaya terhadap bakteri Propionibacterium acnes.

\section{Metode Penelitian}

Penelitian dilakukan di Laboratorium Farmaseutik dan Mikrobiologi, Fakultas Farmasi, Universitas Muslim Indonesia, Makassar, Sulawesi Selatan.

Metode penelitian menguraikan bahan dan alat yang digunakan dan jalannya penelitian.

\section{II.1 Alat dan Bahan}

Alat yang digunakan yaitu, alat-alat gelas bejana, kertas $\mathrm{pH}$, seperangkat alat rotary evaporator, timbangan analitik, viskometer brookfield, wadah serum.

Serta bahan yang digunakan pada penelitian ini yaitu, aquadest, biji pepaya (Carica papaya L.), BHT, etanol 70\%, aquadest, carbopol, medium agar darah, tetrasiklin, metil paraben, $\mathrm{Na} \mathrm{CMC}$, propilen glikol, propil paraben, trietanolamin dan xantan gum.

\section{II.2 Prosedur Penelitian}

\section{Pengelolahan awal sampel biji pepaya}

Biji pepaya diperoleh dari pedagan pepaya yang berasal dari daerah Palopo. Pepaya yang sudah tidak layak jual dikumpulkan dan diambil bijinya. Biji pepaya kemudian dicuci dan dibersihkan dari pengotor. Sapel biji pepaya yang telah bersih dikeringkan selama kurang lebih 4 hari lalu dihaluskan menggunakan blender. Biji pepaya yan telah dihaluskan kemudian ditimbang sebanyak 250 gram lalu dimasukkan kedalam bejana maserasi dan ditambahkan pelarut etanol 70\%. Maserasi dilakukan hingga filtrat tidak berubah warna atau bening, setiap 24 jam pelarut diganti dan dilakukan pengadukan tiga kali sehari. Hasil maserasi disaring untuk memisahkan filtrat dan residunya. Kemudian filtrat tersebut dipekatkan menggunakan rotary evaporator dan pada suhu $45^{\circ} \mathrm{C}$ hingga pelarut menguap dan estrak menjadi lebih kental tetapi masih dapat dituang.

\section{Uji aktivitas antibakteri pada ekstrak biji pepaya}

Dimasukkan medium agar darah sebanyak 9,8 $\mathrm{ml}$ ke dalam vial. Ditambahkan suspensi biakan bakteri Propionibacterium acnes sebanyak satu ose ke dalam vial homogenkan. Dituang ke dalam cawan petri steril secara aseptis dan dibiarkan setengah memadat. Dimasukkan paper disk ke dalam masingmasing konsentrasi ekstrak yaitu 10\%, 15\% dan $20 \%$. Dibiarkan beberapa saat agar paper disk cukup menyerap konsentrasi yang diujikan. Diletakkan paper disk tersebut di atas permukaan medium agar darah untuk masing-masing konsentrasi ekstrak yaitu $10 \%, 15 \%$ dan $20 \%$. Dilakukan hal yang sama untuk aquadest dan tetrasiklin sebagai pembanding lalu diinkubasi dalam inkubator pada suhu $37^{\circ} \mathrm{C}$. Diamati dan diukur zona hambatannya.

\section{Optimasi basis serum}

Optimasi basis serum dapat dilihat pada Tabel 1.

Tabel 1. Rancangan variasi konsentrasi optimasi basis

\begin{tabular}{|c|c|c|c|c|c|c|c|c|c|}
\hline \multirow{3}{*}{ Bahan } & \multicolumn{9}{|c|}{ Konsentrasi (\% b/v) } \\
\hline & \multicolumn{3}{|c|}{ Basis 1} & \multicolumn{3}{|c|}{ Basis 2} & \multicolumn{3}{|c|}{ Basis 3} \\
\hline & Fx1 & $\mathrm{Fx} 2$ & $\mathrm{Fx} 3$ & $\mathrm{Fc} 1$ & $\mathrm{Fc} 2$ & $\mathrm{Fc} 3$ & Fn1 & Fn2 & Fn3 \\
\hline $\begin{array}{l}\text { Xantan } \\
\text { gum }\end{array}$ & 0,8 & 0,1 & 1,2 & - & - & - & - & - & - \\
\hline Carbopol & - & - & - & 1,0 & 1,25 & 1,5 & - & - & -- \\
\hline $\mathrm{Na} \mathrm{CMC}$ & - & - & - & - & - & -- & 8,0 & 9,0 & 10,0 \\
\hline
\end{tabular}

a. Basis 1 (Xantan gum)

Xantan gum di dispersikan menggunakan aquadest secara sedikit demi sedikit dengan pengadukan secara terus menerus hingga terbentuk massa serum.

b. Basis 2 (Carbopol)

Prosedur yang dilakukan sama dengan prosedur pada optimasi basis 1 , tetapi pada tahap optimasi ini menggunakan basis carbopol.

c. Basis 3 (Na CMC)

Prosedur yang dilakukan sama dengan prosedur pada optimasi basis 1 , tetapi pada tahap optimasi ini menggunakan basis Na CMC. 


\section{Formulasi serum}

Formulasi serum ditampilkan pada Tabel 2.

Tabel 2. Rancangan formulasi sediaan serum ekstrak biji pepaya

\begin{tabular}{cccc}
\hline \multirow{2}{*}{ Bahan } & \multicolumn{3}{c}{ Konsentrasi (\% b/v) } \\
\cline { 2 - 4 } & Basis 1 & Basis 2 & Basis 3 \\
& Fx3 & Fc1 & Fn1 \\
\hline Xantan gum & 1,2 & - & - \\
Carbopol & - & 1,0 & - \\
Na CMC & - & - & 8,0 \\
Trietanolamin & - & 1,0 & - \\
Propilen glikol & 15,0 & 15,0 & 15,0 \\
BHT & 0,1 & 0,1 & 0,1 \\
Metil paraben & 0,18 & 0,18 & 0,18 \\
Propil paraben & 0,02 & 0,02 & 0,02 \\
Aquadest ad hingga & 100 & 100 & 100 \\
\hline
\end{tabular}

Xanthan gum didispersikan dalam aqua destilata hingga terbentuk massa serum. Metil paraben, BHT, dan propil paraben dilarutkan dalam propilen glikol. Larutan metil paraben, propil paraben, BHT, dan propilen glikol dicampurkan dalam massa serum yang telah terbentuk didalam lumpang. Basis serum yang telah terbentuk selanjutnya dimasukkan zat aktif dlalu digerus hingga homogen. Dilakukan formulasi serum untuk basis carbopol dan $\mathrm{Na}$ CMC dengan metode yang sama.

\section{Evaluasi sediaan serum}

a. Uji organoleptis

Pengujian serum meliputi warna, aroma, dan sensasi di kulit dengan cara mengamati penampilan visual dan sensasi di kulit.

b. Pengukuran Viskositas dan Sifat Alir

Pengukuran viskositas dilakukan dengan menggunakan alat viskometer Brookfield. Sediaan dimasukkan ke dalam gelas piala kemudian spindel yang sesuai diturunkan hingga batas spindel tercelup ke dalam sediaan, kemudian motor dan spindel dinyalakan. Kecepatan pemutar diatur berturut turut 0,$5 ; 2 ; 5 ; 10$; dan 20 rpm kemudian dibalik dari $20 ; 10 ; 5 ; 2 ;$ dan 0,5 rpm. Angka viskositas yang ditunjukkan oleh jarum merah dicatat, kemudian dikalikan dengan faktor koreksi pada tabel yang terdapat pada brosur alat. Nilai viskositas dihitung kemudian dilakukan plot data yang diperoleh terhadap tekanan geser (dyne/cm) dan kecepatan geser (rpm) (Fatmawati, 2014).

\section{Uji stabilitas}

Stabilitas sediaan dievaluasi pada suhu $40^{\circ}$ $\pm 2^{\circ} \mathrm{C}, 4^{\circ} \mathrm{C} \pm 2^{\circ} \mathrm{C}$, dan $27^{\circ} \pm 2^{\circ} \mathrm{C}$ selama 3 minggu dengan dilakukan pengamatan organoleptis yang meliputi perubahan warna, bau, homogenitas, pengukuran $\mathrm{pH}$, serta pemeriksaan adanya sineresis (Fatmawati, 2014).

a. Uji homogenitas

Uji homogenitas dilakukan dengan cara sampel serum dioleskan pada sekeping kaca atau bahan transparan lain yang cocok, sediaan harus menunjukkan susunan yang homogen dan tidak terlihat adanya butiran kasar (Ditjen POM, 1985). b. $\mathrm{Uji} \mathrm{pH}$

Pengukuran $\mathrm{pH}$ dilakukan dengan mencelupkan $\mathrm{pH}$ meter ke dalam sediaan gel yang telah dibuat sebelum dan setelah diberi kondisi penyimpanan dipercepat yaitu pada suhu $5^{\circ} \mathrm{C}$ dan $35^{\circ} \mathrm{C}$ selama 12 jam sebanyak 10 siklus.

c. Uji sineresis sediaan (72 jam)

Sineresis yang terjadi selama penyimpanan diamati dengan menyimpan sediaan pada suhu \pm $10^{\circ} \mathrm{C}$ selama 24, 48, dan 72 jam. Masing-masing sediaan ditempatkan pada cawan untuk menampung air yang dibebaskan dari dalam gel selama penyimpanan. Sineresis dihitung dengan mengukur kehilangan berat selama penyimpanan lalu dibandingkan dengan berat awal sediaan (Emma et al., 2014).

d. Pengujian viskositas

Pengujian viskositas dilakukan dengan menempatkan sampel dalam viskometer hingga spindel terendam. Spindel diatur dengan kecepatan $50 \mathrm{rpm}$ (Septiani, 2012).

\section{Uji aktivitas antibakteri sediaan serum antijerawat}

Dimasukkan medium agar darah sebanyak 9,8 ml ke dalam vial. Ditambahkan suspensi biakan bakteri Propionibacterium acnes sebanyak satu ose ke dalam vial homogenkan. Dipasang pencadang dalam cawan petri untuk membuat sumur pada medium. Kemudian medium dituang ke dalam cawan petri steril secara aseptis dan dibiarkan memadat. Dimasukkan masing-masing formula Fx3, Fc1 dan Fn1 kedalam sumur medium sebanyak $0,2 \mathrm{~mL}$. Kemudian diinkubasi dalam inkubator pada suhu $37^{\circ} \mathrm{C}$ selama $1 \times 24$ jam. Diamati dan diukur zona hambatannya.

\section{HASIL DAN PEMBAHASAN}

III.1 Pengolahan Awal Sampel

Hasil pengolahan sampel dapat dilihat pada Tabel 1 dan Gambar 1-6. 
Tabel 3. Hasil Pengolahan Sampel

\begin{tabular}{ll}
\hline Sampel biji pepaya segar & $4 \mathrm{~kg}$ \\
\hline Sampel telah diblender (simplisia) & $260,03 \mathrm{gr}$ \\
Jumlah cairan penyari & $3 \mathrm{liter}$ \\
Sampel setelah di rotavapor (ekstrak) & $10,56 \mathrm{gr}$ \\
\hline
\end{tabular}

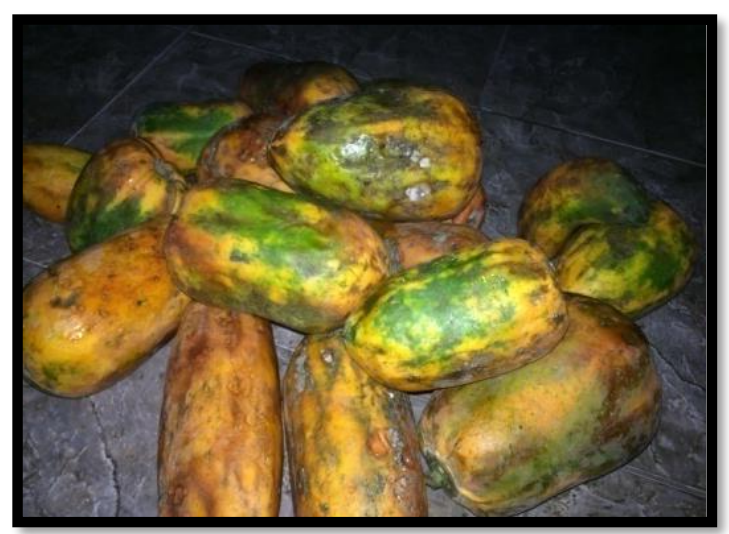

Gambar 1. Sampel buah papaya

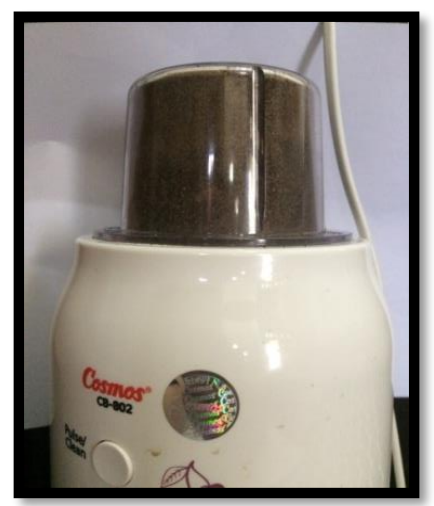

Gambar 3. Penghalusan sampel biji papaya

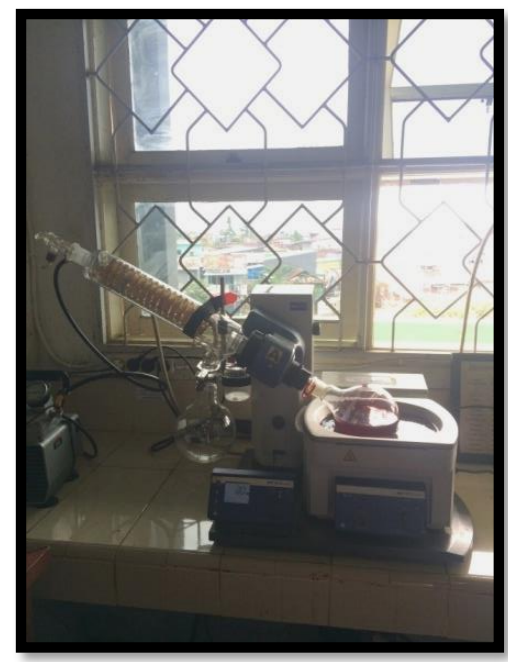

Gambar 5. Penguapan maserat

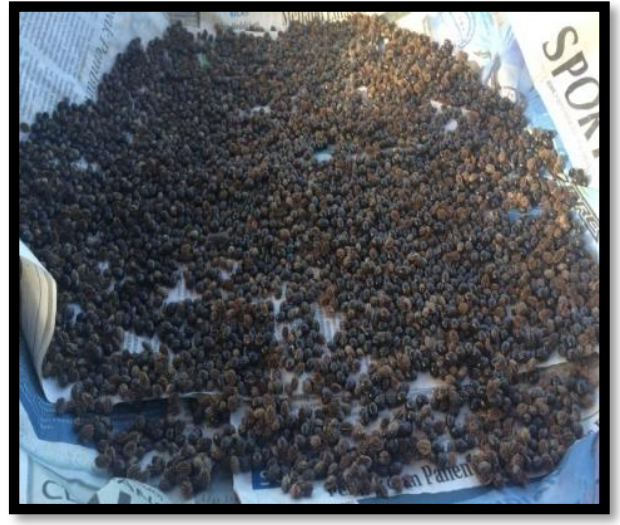

Gambar 2. Pengeringan biji buah pepaya

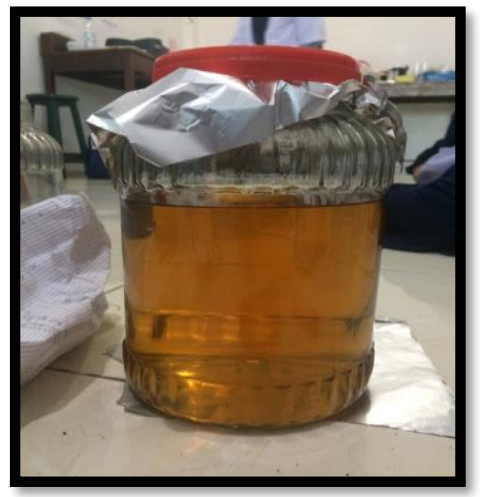

Gambar 4. Proses maserasi

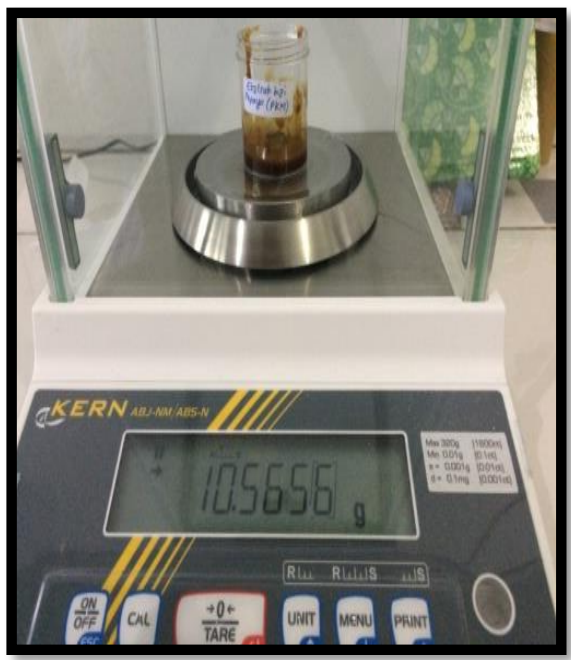

Gambar 6. Ekstrak etanol biji pepaya 


\section{III.2 Pengujian aktivitas antibakteri ekstrak biji pepaya}

Hasil Pengujian aktivitas antibakteri ekstrak biji papaya dapat dilihat pada Tabel 4 dan Gambar 7-10.

Tabel 4. Hasil pengujian aktivitas antibakteri ekstrak biji pepaya

\begin{tabular}{lllllll}
\hline Pengujian & Bakteri uji & Konsentrasi & Zona hambat (mm) & Rata-rata \\
\hline Ekstrak etanol biji & P. Acnes & $10,0 \%$ & 9,10 & 9,11 & 10,80 & 9,67 \\
pepaya & & $15,0 \%$ & 11,56 & 9 & 10,92 & 10,49 \\
& & $20,0 \%$ & 7,93 & 8,33 & 10,28 & 8,84 \\
Tetrasiklin & $20 \mu \mathrm{g} / \mathrm{ml}$ & 9,98 & 10,31 & & \multicolumn{2}{c}{10,41} \\
Aquadest steril & & - & - & & \multicolumn{2}{c}{-} \\
\hline
\end{tabular}

Pada proses pengujian aktivitas antibakteri didapatkan hasil bahwa efek antibakteri yang terlihat paling baik yaitu pada konsentrasi $15 \%$ dimana pada konsentrasi ini luas zona hambat ekstrak etanol biji papaya terhadap bakteri Propionibacterium acnes adalah 10,49 $\mathrm{mm}$. Dimana luas zona hambat tersebut mendekati luas zona hambat tetrasiklin yang digunakan sebagai kontrol positif yaitu 10,64 mm.

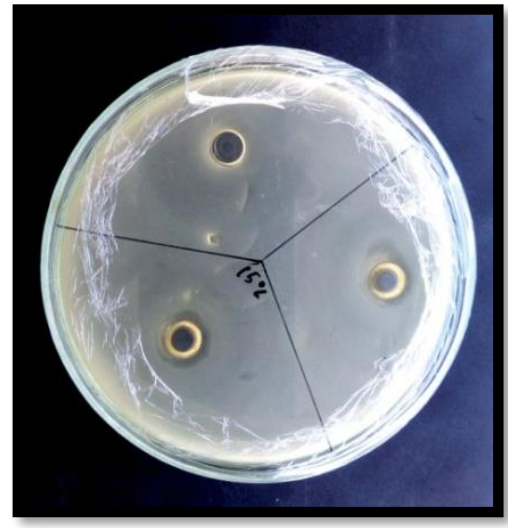

Gambar 7. Uji aktivitas antibakteri 15\% (Besar zona hambat ekstrak etanol biji pepaya konsentrasi $15 \%$ )

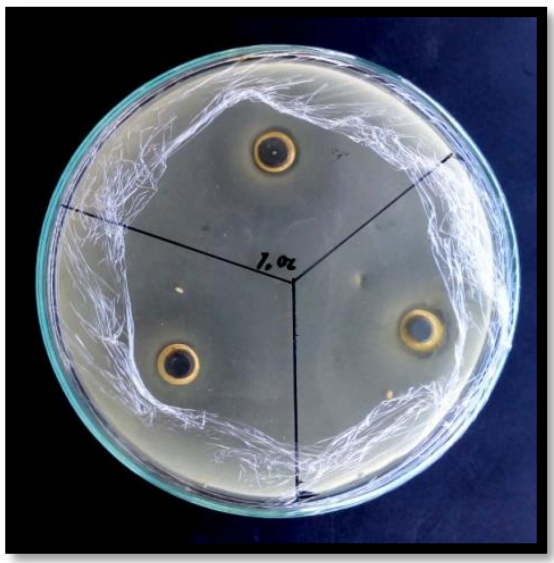

Gambar 9. Uji aktivitas antibakteri ekstrak $20 \%$ (Besar zona hambat ekstrak etanol biji pepaya $20 \%$ )
Bahkan pada konsetrasi terendah pun (10\%) ekstrak etanol biji pepaya dapat menghambat pertumbuhan bakteri. Adapun pada konsetrasi 20\% luas zona hambat yang terbentuk lebih kecil dari konsetrasi $15 \%$ dan $10 \%$, hal ini terjadi mugkin karna adanya faktor kesalahan seperti ppengerjaan yang kurang aseptis.

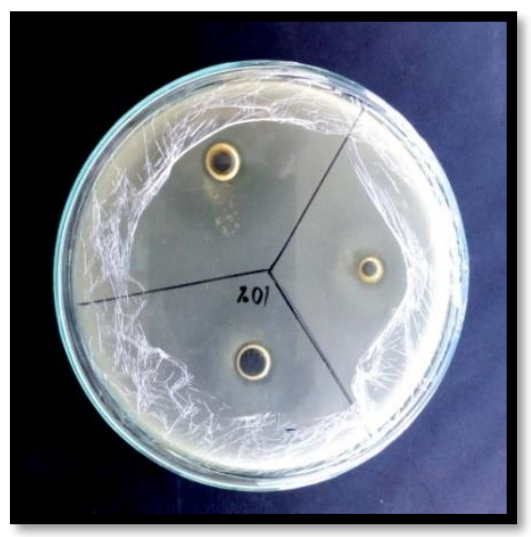

Gambar 8. Uji aktivitas antibakteri 15\% (Besar zona hambat ekstrak etanol biji pepaya konsentrasi $10 \%$

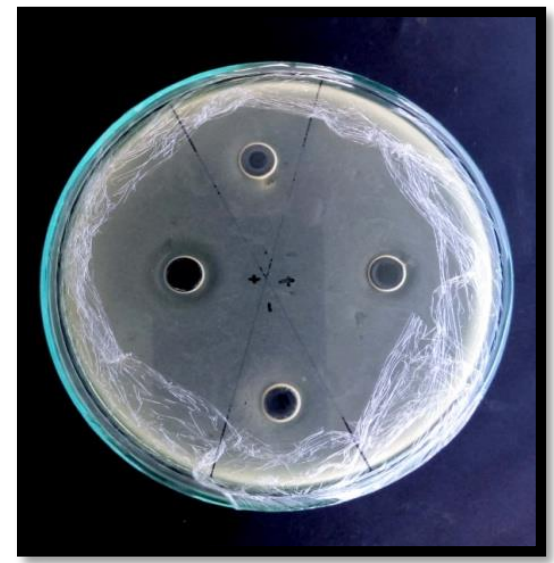

Gambar 10. Kontrol positif dan negative (Besar zona hambat tetrasiklin dan aquades sebagai pembanding) 


\section{III.3 Pengujian optimasi basis sediaan serum}

Hasil Pengujian optimasi basis sediaan serum dapat dilihat pada Tabel 5 dan Gambar 11-13.

Tabel 5. Hasil optimasi basis sediaan serum

\begin{tabular}{llll}
\hline \multirow{2}{*}{ No. } & \multirow{2}{*}{ Formula } & \multicolumn{2}{c}{ Hasil Uji Organoleptis } \\
\cline { 3 - 4 } & & \multicolumn{1}{c}{ Warna } & \multicolumn{1}{c}{ Konsistensi } \\
\hline 1 & Fx1 & Bening kekuningan & Encer \\
2 & Fx2 & Bening kekuningan & Encer \\
3 & Fx3 & Bening kekuningan & Agak kental \\
4 & Fc1 & Bening & Agak kental \\
5 & Fc2 & Bening & Kental \\
6 & Fc3 & Bening & Sangat kental \\
7 & Fn1 & Bening & Agak kental \\
8 & Fn2 & Bening & Kental \\
9 & Fn3 & Bening & Sangat kental \\
\hline
\end{tabular}

Dari hasil optimasi basis sediaan serum maka basis yang yang mendekati sifat fisik serum yang paling baik yaitu formula Fx3, Fc1 dan Fn3.

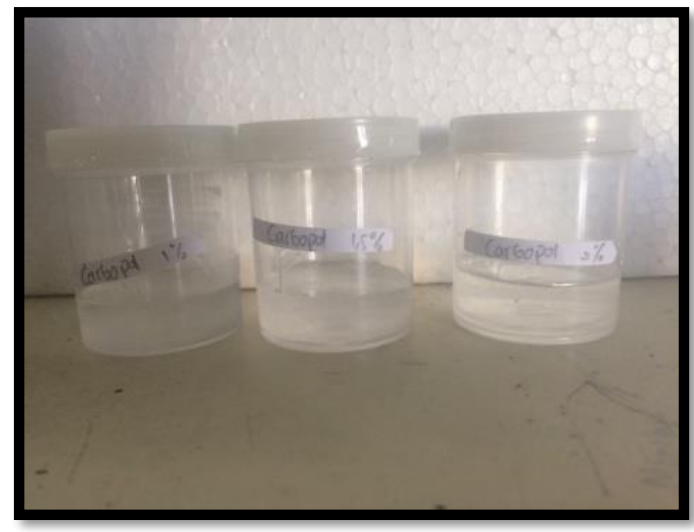

Gambar 11. Hasil optimasi basis carbopol

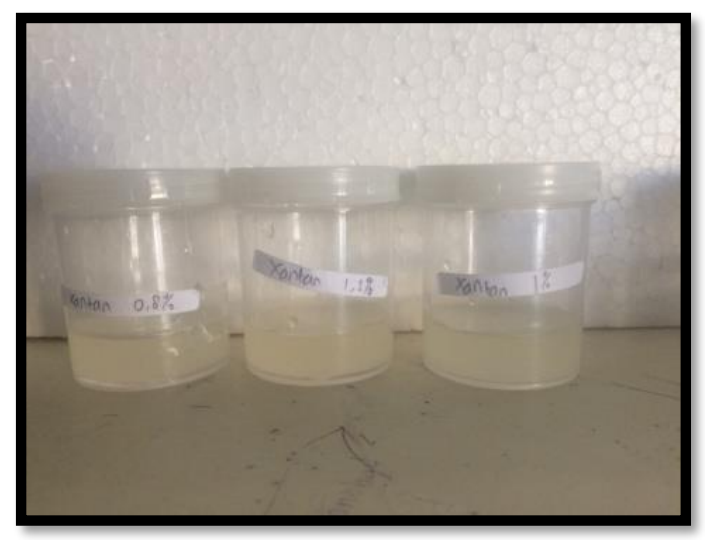

Gambar 13. Hasil optimasi basis xanthan gum

\section{III.4 Hasil Formulasi Serum}

Dari konsentrasi basis optimum kemudian di formulasi menjadi sediaan serum yang mana basis Fx3 (Gum Xantan 1,2\%), Fc1 (Carbopol 1\%) dan
Selanjutnya akan dilakukan pengembangan optimasi basis untuk memformulasi sediaan serum dengan sifat farmaseutik (stabilitas) yang optimal.

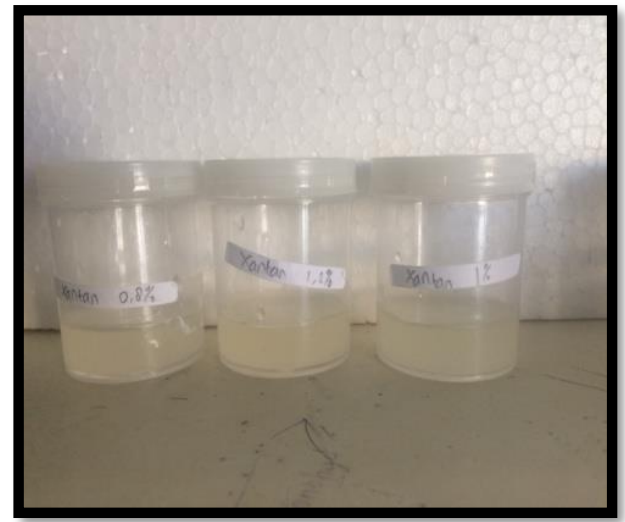

Gambar 12. Hasil optimasi basis Na CMC

Fn3 (NaCMC 8\%). Yang mana hasil yang didapat masing-masing berwarna coklat dengan konsistensi sediaan yang kental. Hasil formulasi serum dapat dilihat pada Gambar 14-16. 


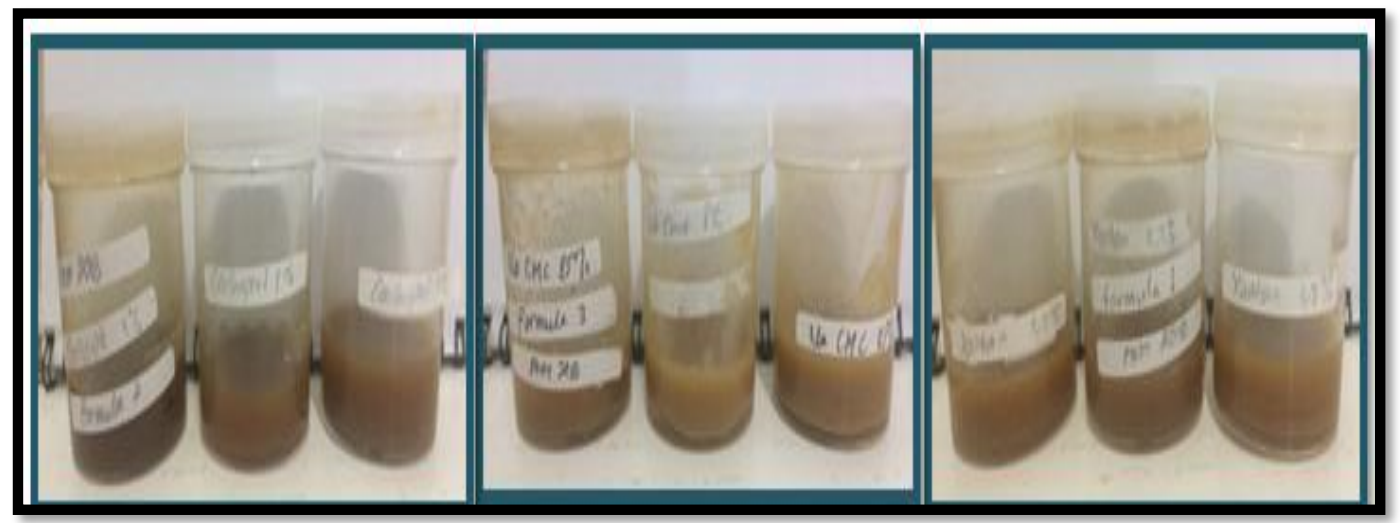

Gambar 14. Hasil formula Fc1 Gambar15. Hasil formula Fn3 Gambar16. Hasil formula Fx3

III.5 Evaluasi Sediaan Serum

Tabel 6. Hasil pengujian organoleptis

\begin{tabular}{lllll}
\hline \multirow{2}{*}{ No. } & \multirow{2}{*}{ Formula } & \multicolumn{3}{c}{ Sifat Organoleptis } \\
\cline { 3 - 5 } & & Warna & Aroma & \multicolumn{1}{c}{ Sensasi di kulit } \\
\hline 1 & Fx3 & Coklat Pekat & Khas & Lengket \& meresap \\
2 & Fc1 & Coklat & Khas & Lengket \& meresap \\
3 & Fn3 & Coklat Muda & Khas & Lengket \& meresap \\
\hline
\end{tabular}

Dari konsentrasi basis yang optimum kemudian di formulasi menjadi sediaan serum yang mana basis Fx3 (Gum Xantan 1,2\%), Fc1 (Carbopol 1\%) dan Fn3 (NaCMC 8\%). Hasil yang didapat masing-masing berwarna coklat dengan konsistensi sediaan yang kental dan sensasi pada kulit lengket dan meresap. Hasil evaluasi sediaan serum dapat dilihat pada Tabel 6 .

\section{III.6 Uji Stabilitas}

Tabel 7. Hasil pengujian stabilitas

\begin{tabular}{llll}
\hline \multirow{2}{*}{ No. } & \multirow{2}{*}{ Formula } & \multicolumn{2}{c}{ Hasil Uji Stabilitas } \\
\cline { 3 - 4 } & & Homogenitas & $\mathbf{p H}$ \\
\hline 1 & Fx3 & Homogen & 6 \\
2 & Fc1 & Homogen & 5 \\
3 & Fn3 & Homogen & 5 \\
\hline
\end{tabular}

Dari hasil pengamatan masing-masing sediaan tampak homogen. $\mathrm{pH}$ sediaan dari formula Fx3 yaitu 6, sedangkan pada formula Fc1, dan Fn3 adalah 5 dimana ketiga formulasi tersebut masih berada dalam rentang $\mathrm{pH}$ kulit yaitu, 4,5 sampai 6,5. Hasil Uji stabilitas dapat dilihat pada Tabel 7.

\section{III.7 Hasil Uji Aktivitas Sediaan Serum}

Tabel 8. Hasil pengujian aktivitas sediaan serum terhadap Propinibacterium acne

\begin{tabular}{llllll}
\hline Kode Formula & Konsentrasi Basis & \multicolumn{3}{c}{ Zona hambat $(\mathbf{m m})$} & Rata-rata \\
\hline Fx3 & Xantan Gum 1,2 \% & 10,50 & 11,82 & 11,86 & 11,39 \\
Fc1 & Carbopol 1\% & 9,53 & 9,31 & 11,09 & 9,98 \\
Fn3 & Na CMC 8\% & 11,60 & 10,55 & 11,29 & 11,13 \\
\hline
\end{tabular}

Pada proses pengujian aktivitas antibakteri yang ditampilkan pada Tabel 8, didapatkan hasil bahwa efek antibakteri yang terlihat paling baik yaitu pada basis xantan gum dimana pada konsentrasi ini luas zona hambat terhadap bakteri Propionibacterium acnes adalah 11,39 $\mathrm{mm}$.

\section{Kesimpulan}

Dari hasil pengujian ini diadapatkan bahwa sediaan serum antijerawat ekstrak biji pepaya dengan Kode Formula Fx3 merupakan sediaan yang terbaik dibanding Formula lainnya, dengan besar zona hambat $11,39 \mathrm{~mm}$ lebih besar dari standar tetrasiklin 10,41 mm. Yang mana Kode Formula Fx3 merupakan sediaan yang paling stabil dan diterima baik pada permukaan kulit.

\section{Ucapan Terima Kasih}

Ucapan terima kasih kami haturkan kepada pihak Laboratorium Farmaseutikal Farmasi UMI, Laboratorium Mikrobiologi Farmasi UMI, dan semua pihak baik itu Mahasiswa dan Civitas 
Akademika yang telah membantu dalam penyelesaian artikel ini.

\section{Daftar Pustaka}

Ditjen POM, 1985. Formularium Kosmetika Indonesia. Jakarta. Departemen Kesehatan RI.

Draelos, Z.D. \& Lauren, A.T., 2010. Cosmetic Formulation of Skin Care Products. 326. Taylor and Francis Group. New York.

Fatmawati N, Anwar E, Azizahwati. Formulasi Serum Penghambat Kerja Tirosinase yang Mengandung Fitosom Ekstrak Biji Lengkeng (Dimocarpus longan Lour) Menggunakan Eksipien Koproses Kasein Xanthan Gum. FF UI. 2014.

Emma S.K, Iskandarsyah, Praptiwi. Evaluasi, Uji Stabilitas Fisik dan Sineresis Sediaan Gel yang Mengandung Minoksidil, Apigenin dan Perasan Herba Seledri (Apium graveolens L.). Jurnal. Fakultas Farmasi UI. Bul. Penelit. Kesehatan, Vol 42, No. 4, Desember 2014: 213-222

Mitsui, T. 1997.New Cosmetic Science.Tokyo : Shiseido Co., Ltd.

Naibaho, Olivia H. Paulina V.Y. Yamlean, Weny Wiyono., 2013. Pengaruh Basis Salep Terhadap Formulasi Sediaan Salep Ekstrak Daun Kemangi (Ocimun Sanctum L.) Pada Kulit Punggung Kelinci Yang Dibuat Infeksi Staphyloccocus Aureus. Jurnal Ilmiah Farmasi. UNSRAT. Vol 2 N0 02. ISSN 2302-2493.

Rahmi AH, Cahyanto T, Sujarwo T, Lestari RI. Uji Aktivitas Antibakteri Ekstrak Daun Beluntas (Pluchea indica (L.) LESS.) Terhadap Propionibacterium acnes Penyebab Jerawat. Jurnal. Fakultas Sains dan Teknologi UIN Sunan Djati Bandung. Edisi Juni 2015. Volume IX No.1.

Septiani S, Wathoni N, Mita SR. Formulasi sediaan masker gel antioksidandari ekstrak etanol biji melinjo (Gnetum gnemon Linn.). Jurnal Universitas Padjadjaran. 2011;1(1):4-24

Syarifah F, Mulyanti D, Priani SE. Formula Edibe Film Ekstrak Biji Pepaya (Carica Papaya L.) dan Uji Aktifitasnya terhadap Bakteri Klebsiella Penumoniae dan Staphylococcus Aureus. Prosiding Penelitian SPeSIA Unisba. 2015.

Tranggono, Retno I. Buku Pegangan Ilmu Pengetahuan Kosmetik. PT Gramedia Pustaka : Jakarta 